\title{
The Impact of CLIL on the Acquisition of the Learning to Learn Competence in Secondary School Education in the Bilingual Programmes of Castilla-La Mancha
}

\author{
Esther Nieto Moreno de Diezmas \\ University of Castilla-La Mancha (UCLM)
}

Received: 16 March 2014 / Accepted: 14 November 2014

ISSN: $1697-7467$

\begin{abstract}
In this paper the influence of bilingual education on the acquisition of the key learning to learn competence is examined. To do so, bilingual $(\mathrm{n}=1,966)$ and non-bilingual students $(n=14,713)$ of Castilla-La Mancha enrolled in the $2^{\text {nd }}$ year of Compulsory Secondary Education took a series of tests designed to assess two dimensions of the competence of learning to learn: "metacognitive strategies", made up of two learning standards related to metacognitive processes, and "learning strategies", a dimension consisting of five standards connected to cognitive processes. Results showed bilingualism had a significant effect on the acquisition of the key competence of learning to learn.

Keywords: Content and Language Integrated Learning (CLIL), learning to learn, metacognitive strategies, learning strategies.

Impacto del AICLE en la adquisición de la competencia de aprender a aprender en educación secundaria en los programas bilingües de Castilla-La Mancha

RESUMEN: Este trabajo estudia la influencia de las enseñanzas bilingües en la adquisición de la competencia clave de aprender a aprender. Para ello, alumnos bilingües $(n=1,966)$ y no bilingües ( $\mathrm{n}=14.713)$ de $2^{\circ} \mathrm{ESO}$ de Castilla-La Mancha realizaron una serie de tests que han servido para evaluar dos dimensiones de la competencia en aprender a aprender: "estrategias metacognitivas", compuesta por dos estándares de aprendizaje relacionados con procesos metacognitivos y "estrategias de aprendizaje", dimensión desglosada en cinco estándares conectados con procesos cognitivos. Los resultados muestran un impacto significativo del bilingüismo en la adquisición de la competencia clave aprender a aprender.

Palabras clave: Aprendizaje Integrado de Contenidos y Lengua (AICLE); aprender a aprender, estrategias metacognitivas, estrategias de aprendizaje.
\end{abstract}

\section{INTROdUCTION}

Bilingualism characterized by the teaching of curricular areas through a foreign language (CLIL / AICLE / EMILE) is becoming more and more popular. The promising results obtained from the pioneering immersion programmes in Canada and the USA (Cloud, Genesee \& Hamayan, 2000; Cummins \& Swain, 1986; Day and Shapson, 1996; Genesee, 1987, 1991; 
Lapkin, Hart, \& Turnbull, 2003; Swain \& Lapkin, 1985, 1986; Turnbull, Lapkin, \& Hart, 2001) have led to the progressive introduction of bilingual education worldwide. Thus, the European institutions have considered that learning foreign languages is a means of cohesion and community building and, therefore, have facilitated the rapid expansion of Content and Language Integrated Learning (CLIL), considering it to be a model of effective language learning in meaningful and functional environments.

Since then, "CLIL has become a highly topical issue due to its substantial increase in popularity" (Lagasabaster \& López Belochi, 2015: 42), and there is an important body of research on its multi-faceted benefits. In some studies it has been reported that CLIL provides more productive pedagogies which foster the acquisition of learning skills and promote cognitive development. In this sense, empirical evidence is shown in this paper, as regards the influence of CLIL on the acquisition of learning to learn, which is included among the key competences for lifelong learning.

\section{Literature REVIEW}

One of the key features of CLIL is its dual focus on the integrated acquisition of content and a foreign language. As Mehisto, Marsh and Frigols (2008: 9) define it, "CLIL is a dual-focused educational approach in which an additional language is used for the learning and teaching of both content and language". Therefore, the emphasis of CLIL methodology is on both language and content learning, and the results obtained from CLIL students for both aspects have been studied.

Regarding the impact of CLIL on the development of language competences, research confirms that the integrated curriculum is more effective in the acquisition of a second language than traditional EFL classes (Admiraal, Westhoff \& de Bot, 2006; Alonso, Grisaleña \& Campo, 2008; Jimenez Catalán \& Ruiz de Zarobe, 2009; Lagasabaster, 2008; LorancPaszylk, 2009; Lawrence, 2010; Navés, 2011; Navés \& Victori, 2010; Pérez Cañado, 2011; San Isidro, 2009, 2010; Várkuti, 2010). Nevertheless, some language areas particularly benefit from CLIL, such as receptive skills, vocabulary, morphology, creativity, fluency and quantity, emotive and affective outcomes (Dalton-Puffer, 2008), and oral production (Dalton-Puffer, 2011). On the other hand, productive vocabulary, informal language, some aspects of writing (accuracy, discourse skills), pronunciation and some aspects of syntax, are areas in which CLIL does not have a significant effect (Ruiz de Zarobe, 2011)

As regards the outcomes in the acquisition of the content taught through a foreign language, research shows that greater mastery of a foreign language is not achieved at the expense of learning content. Thus, CLIL students acquire the content of the subjects conveyed in a foreign language to the same or even to a greater extent than their non-CLIL peers (Badertscher \& Bieri, 2009; Bergroth, 2006; Jabrun, 1997; Grisaleña, Campo \& Alonso, 2009; Housen, 2002; Jäppinen, 2005; Lamsfuß-Schenk, 2002; Madrid, 2011; Seikkula-Leino, 2007; Stohler, 2006; Van de Craen, Lochtman, Ceuleers, Mondt \& Allain, 2007).

This ability the CLIL students have to take in the contents just as their non-CLIL counterparts do -even if they have the additional obstacle of understanding concepts by means of a foreign language- can indicate that they are more efficient learners (Jabrun, 1997). In this sense, Halbach (2009: 21) points out that integrated content and foreign language 
acquisition requires double the cognitive effort made by non-CLIL learners, and because of this, it has a positive effect on the understanding and mental integration of content, so that, as Dalton-Puffer states (2008: 143) "rather than being a hindrance, L2 processing actually has a strong potential for the learning of subject-specific concepts".

Therefore, to enable integrated content and language acquisition, CLIL methodology focuses on a third element: learning skills. Thus, in the opinion of Mehisto et al. (2008: 12), to connect content and language, it is necessary to provide students with learning skills that can support integrated learning. Hence, the goals in a CLIL classroom are not only the acquisition of content and language, but also, the development of learning skills.

Additionally, according to Coyle (1999), the acquisition of content by means of a second language takes place within the framework of a communicative process in which cognitive skills and intercultural strategies are activated. Therefore, a fourth element must be added to the Mehisto et al. triad (2008) to complete Coyle's 4Cs framework: culture (intercultural understanding). The 4Cs framework explains how, thanks to the confluence and integration of content, communication, culture and cognition, learning occurs in CLIL contexts. Thus, for Coyle (2011), the cognitive aspect and its development is one of the goals of CLIL "CLIL is seen as an approach to education which incorporates ways of using different languages in order to extend learner's cognitive, linguistic and cultural experiences" (Coyle, 2011: 50).

The focus that CLIL methodology has on learning skills and cognition seems to have a positive effect on their acquisition. Researchers show that CLIL promotes cognitive flexibility, cognitive engagement (Coyle et al., 2010: 10, 29), enhances cognitive functioning, problemsolving skills and higher order thinking (Bialystok, Craik \& Freedman, 2007; Kormi-Nuori, Shojaei, Moniri, Gholami, Moradi, Akbari Zardkhaneh, Saeed \& Nilsson, 2008; Mehisto \& Marsh, 2011). In the same vein, Muñoz (2002: 36) states that "CLIL may strengthen learners' ability to process input, which prepares them for higher level thinking skills, and enhances cognitive development" (Muñoz, 2002:36).

Moreover, there are studies in Spanish settings which show the CLIL students have better commands of learning strategies. Thus, Grisaleña et al. (2009), adapted the SILL (Strategy Inventory for Language Learning) developed by R. Oxford for high school students, and showed that CLIL learners used, both direct and indirect learning strategies to a greater extent than mainstream students. In turn, Mendez (2014) examined the insights teachers had as regards the cognition development of their CLIL students and concluded that integrated learning was connected to the development of critical thinking and fostered both lower and higher order thinking skills: remembering, understanding, applying, analysing, evaluating and creating.

In this sense, the aim of this paper is to provide new evidence on the contribution of CLIL to the acquisition of learning strategies and particularly to the development of the learning to learn competence, which was included among the key competences for lifelong learning in the Recommendation of the European Parliament and the Council of $18^{\text {th }}$ of December 2006 on key competences for lifelong learning (2006/962 / EC). This Recommendation considers the crucial role of learning to learn for the development of all key competences, because it supports all learning activities. The acquisition of key competences and particularly, learning to learn is essential for personal fulfilment in the knowledge society, and therefore, it is important to research the contribution CLIL makes to this. To do so, the learning strategies of 13 and 14 -year-old CLIL students in the $2^{\text {nd }}$ year of Secondary 
Education in Castilla- La Mancha, have been analysed and compared to the corresponding results obtained by their non-CLIL counterparts.

\section{2. МеthoD}

\subsection{Objectives, research questions and hypothesis}

The main objective of this paper is to check whether there is a connection between CLIL and the acquisition of the key competence of learning to learn.

The following research questions are posed in this study:

1) Do students in CLIL programmes develop greater mastery in the different dimensions and learning standards related to the key competence of learning to learn than their non-CLIL peers?

2) Do CLIL students show greater overall acquisition of the key competence of learning to learn than non-CLIL students?

Based on previous studies, a significant relationship between CLIL and the development of learning strategies is expected, so that bilingual students would be more competent in learning to learn than mainstream students.

\subsection{Setting: CLIL in Castilla-La Mancha}

To answer the research questions, we have analysed data from CLIL and non-CLIL students in the $2^{\text {nd }}$ year of secondary school (13-14- year-olds) in Castilla-La Mancha. CLIL programmes of Castilla-La Mancha have been implemented since 2005 under the denomination of the European Sections. At the time of this study, the regulation in force provided that in European Sections at least two curricular subjects were to be taught by means of the foreign language of the Section (especially by means of English, the most widespread foreign language in the CLIL programmes of Castilla-La Mancha), and at least 50\% of the instruction time. The most frequent subjects taught by means of English were natural sciences, social sciences and mathematics, in that order.

Access students have to European Sections is regulated by the general rules of admission applicable to all schools. Selection of CLIL students on the basis of their academic or linguistic merits is explicitly forbidden. Access of new schools to CLIL programmes is regulated by the local authorities by means of annual calls for schools projects in which the interested education establishments must demonstrate they are prepared to become a European Section and that there are enough teachers who have the foreign language competence required (B2 CEFR) to implement the integrated curriculum.

Contrary to abundant research on bilingual experiences in other parts of Spain, such as Andalusia, the Basque Country, Madrid, Catalonia and Galicia, among others, studies on CLIL in Castilla-La Mancha are very scarce, so that, to my knowledge, only some aspects, such as characterization of the implementation of CLIL in Castilla-La Mancha (Fernández Cézar, Aguirre Pérez \& Harris, 2009), the development of emotional competence through CLIL (Nieto Moreno de Diezmas, 2012) and teacher training (Fernández-Cezar, Aguirre Pérez 
\& Harris, 2013) have been studied. In fact, there is no reference to CLIL implementation and research in Castilla-La Mancha in the seminal book CLIL in Spain (Lagasabaster \& Ruiz de Zarobe, 2010).

\subsection{Sample}

Data analysed in this study comes from all students enrolled in the $2^{\text {nd }}$ year of secondary education in Castilla-La Mancha and were collected by the Evaluation Office of the Ministry of Education of Castilla-La Mancha during the General Diagnostic Assessment, regulated by Resolutions 16/02/2009 and 28/10/2010, which in turn develop the requirement of Art. 144 of the Organic Law of Education 2/2006. The sample is the census. Although the aim of the General Diagnostic Assessment is to collect information on the acquisition of the key competences in order to make decisions to improve the quality and equity of the education system, these data can provide valuable information on important aspects of the learning process CLIL students undergo. The processed data have been divided into two groups: the control group $(n=14,713)$, consisting of students in regular programmes (non-CLIL group) and the experimental group $(n=1,966)$, made up of students enrolled in European Sections (CLIL group). The age of participants ranged between 13 and 14 years old.

\subsection{Instruments}

For data collection, a set of Assessment Units (AUs), developed by the Evaluation Office of the Ministry of Education of the Regional Government of Castilla- La Mancha during the General Diagnostic Assessment, was used. The AUs are intercompetential which means that each unit assesses various key competences and conversely, key competences are evaluated by means of more than one AU. Thus, to assess the acquisition of the key competence in learning to learn, seven indicators spread over four AUs (AUs 3,8,10 and 16) were considered.

The AUs were structured around three elements: a scenario, a series of tasks and a set of learning standards, which were specific, observable and capable of providing relevant information. The purpose of the scenario was to provide a real-world situation that catered to the interests and motivations of the students, and fostered the mobilization of knowledge and skills. After exposition of the scenario, students had to solve a series of tasks connected to a system of learning standards that were grouped into two dimensions: "metacognitive strategies" and "learning and self-regulation strategies". There were seven tasks in total, two of which were presented as multiple-choice questions in which the students had to select one out of four options. The scores for these tasks were 1 for correct answers and 0 for incorrect ones. The remaining five tasks were presented in the form of questions with open answers; for three of which a maximum of 2 points was awarded and a maximum of 3 was awarded for the other two tasks. Each task provided information on the accomplishment of a learning standard and each learning standard was related to the acquisition of meta-cognitive or cognitive skills and processes. 
Table 1. Dimensions, standards, process and skills

\begin{tabular}{|c|c|c|c|}
\hline DIMENSION & STANDARD & PROCESS & SKILLS \\
\hline \multirow{5}{*}{$\begin{array}{l}\text { Learning and self- } \\
\text { regulation strategies }\end{array}$} & $\begin{array}{l}\text { Organization of information } \\
\text { in concept maps. }\end{array}$ & Cognitive & $\begin{array}{l}\text { Organize: structure, classify, } \\
\text { integrate, relate. }\end{array}$ \\
\hline & $\begin{array}{l}\text { Integration of information in } \\
\text { content sheets }\end{array}$ & Cognitive & $\begin{array}{l}\text { Organize: structure, classify, } \\
\text { integrate, relate }\end{array}$ \\
\hline & $\begin{array}{l}\text { Outlining the main ideas } \\
\text { after a first reading of a text. }\end{array}$ & Cognitive & $\begin{array}{l}\text { Synthesize: define, summarize, } \\
\text { plan }\end{array}$ \\
\hline & Planning a written text. & Cognitive & Plan \\
\hline & $\begin{array}{l}\text { Presenting clear logically } \\
\text { ordered texts. }\end{array}$ & Cognitive & Present, explain, apply \\
\hline \multirow[t]{2}{*}{$\begin{array}{l}\text { Metacognitive } \\
\text { strategies }\end{array}$} & $\begin{array}{l}\text { Identification of own } \\
\text { learning styles. }\end{array}$ & Metacognitive & $\begin{array}{l}\text { Review: meta-evaluate, be } \\
\text { rigorous }\end{array}$ \\
\hline & Self-evaluation of results & Metacognitive & $\begin{array}{l}\text { Review: meta-evaluate, be } \\
\text { rigorous }\end{array}$ \\
\hline
\end{tabular}

The data were analysed by means of SPSS (Statistical Package for Social Science). For the reliability index, Cronbach's alpha was used. The reliability index was 0.561 , which means that it is acceptable. The distribution was normal, as evidenced by the KolmogorovSmirnov normality test. As the variable was made up of two categories (CLIL/ no-CLIL), independent samples t-tests were applied.

Data are presented graphically with scores expressed on a 0 to 10 basis, so that by using a single scale, the results obtained in the different dimensions and standards, could be compared.

\section{Results AND DisCuSSION}

3.1. Research question 1: Do students in CLIL programmes develop greater mastery in the different dimensions and learning standards related to the key competence of learning to learn than their non-CLIL peers?

In answer to this question, the results of the two dimensions assessed: "metacognitive strategies" and "learning and self-regulation strategies" were analysed. The CLIL group scored 5.95 points out of 10 in the dimension "learning and self- regulation strategies" and 6 points in the dimension "metacognitive strategies", whereas the punctuations of the non-CLIL group were 4.91 and 5.45 respectively. As a result, CLIL students scored higher than their peers in both dimensions, and the differences were significant as the p-value $=0.000$ in both cases.

The broadest difference between the two groups was observed in the dimension that measured learning and self-regulation strategies, in which mainstream learners (Non-CLIL) failed to gain 5 points out of 10 , a result significantly lower than that obtained in the dimension that values metacognitive strategies. However, CLIL students scored around 6 out of 10 in both dimensions. These results indicated that the metacognitive and learning and self-regulation strategies of the CLIL students were developed in a balanced fashion in contrast to what happened with their non-CLIL peers who struggled in the use of learning and self-regulation strategies. 
In the following figures, standards of each dimension are analysed. In figure 1, the standards that made up the dimension "learning strategies and self-regulation" are itemised, and, as can be seen, CLIL students obtained higher results in all standards, and the differences were significant in all of them, since in every case, the p-value $=0.000$

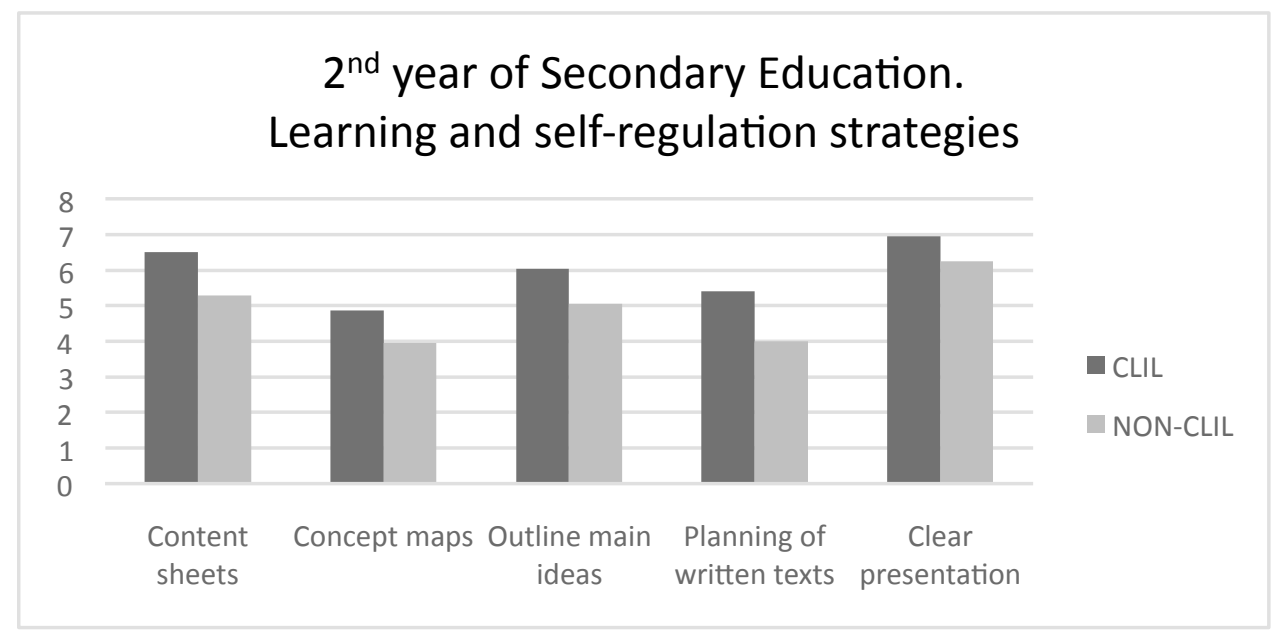

Figure 1. Learning to learn (LtL) in $2^{\text {nd }}$ year of Secondary Education. Results of the standards of the dimension "learning and self-regulation strategies"

Both groups showed lower results when it came to creating concept maps and planning a written text, standards in which the non-CLIL group scored below 5 out of 10 . However, despite the fact that the CLIL group also obtained its lowest scores in the same standards, it is in these, together with the standard that assessed elaboration of content sheets, where CLIL had a more positive impact, as differences with the control group were proportionally greater. These three standards are connected with higher order cognitive skills. Drawing on Bloom's taxonomy reviewed by Anderson and Krathwohl, the standard used to assess the ability to plan a written text is related to the higher order thinking skill (HOTS) of "creating", located at the top of the taxonomy, while organization of information in content sheets and concept maps relate to the higher order thinking skill of "analysing".

The differences were also significant, albeit not to such a great extent, in the standards "outline the main ideas after a first reading of a text" and in "presenting clear logically ordered texts". These standards in which the differences were less marked are related to lower order thinking skills (LOTS) as "understanding and application". In conclusion, greater differences between CLIL and non-CLIL learners were detected when assessing standards connected to higher order thinking skills (HOTS).

On the other hand, regarding the results obtained in each standard used to evaluate the acquisition of the dimension "metacognitive strategies", CLIL students outstripped their counterparts in both "identify the own learning style" and "self-evaluation of results", and differences were significant, as in both standards $p$-value $=0.000$. 


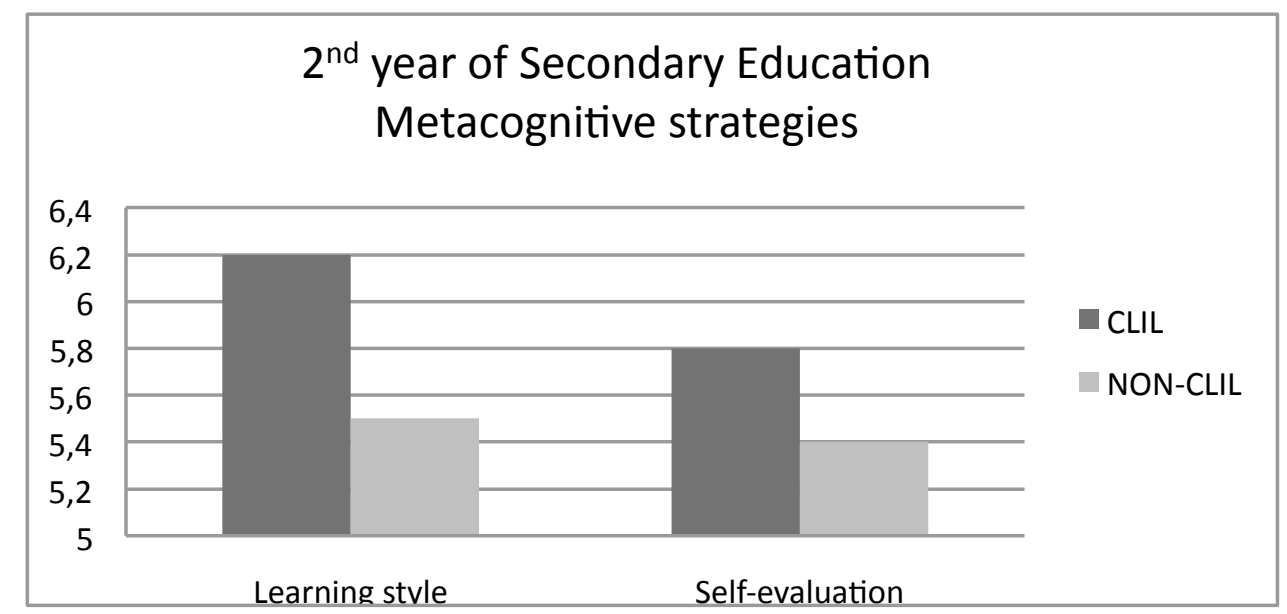

Figure 2. Learning to learn (LtL) in $2^{\text {nd }}$ year of Secondary Education. Results of the standards of the dimension "metacognitive strategies"

If we compare the two standards of the dimension that assesses metacognitive strategies, greater differences between the two groups can be observed in the learning style. CLIL students consider that they learn more with problem-solving activities and they prefer tasks that are more cognitively demanding, rather than those of a more mechanical nature, which they feel are less useful for learning. This perspective significantly differs from that of the non-CLIL students.

Moreover, CLIL students scored significantly higher in self-evaluation which is a quality linked to more effective learning, because it provides learners with information about what they know and what they do not, and this is one of the most important starting points for self-regulated learning (Butler \& Winne, 1995).

In short, CLIL students showed greater expertise for reflecting on their own learning processes, on how they learn, and on what their own abilities and their own learning outcomes are, and they also displayed a higher mastery of lower and higher thinking skills than their counterparts.

\subsection{Research question 2: Do CLIL students show greater overall acquisition of the key competence of learning to learn than non-CLIL students?}

In answer to this research question, the overall acquisition of the learning to learn competence was calculated as being the average of all learning standards evaluated in both dimensions: "metacognitive strategies", and "learning strategies and self-regulation" on a scale out of 10 .

As can be seen in figure 3, CLIL students obtained higher average scores than mainstream ones, with significant differences, since the $\mathrm{p}$-value $=0.000$. This result showed that CLIL had a clear positive impact on the acquisition of the learning to learn competence in secondary school students enrolled in the $2^{\text {nd }}$ year. 


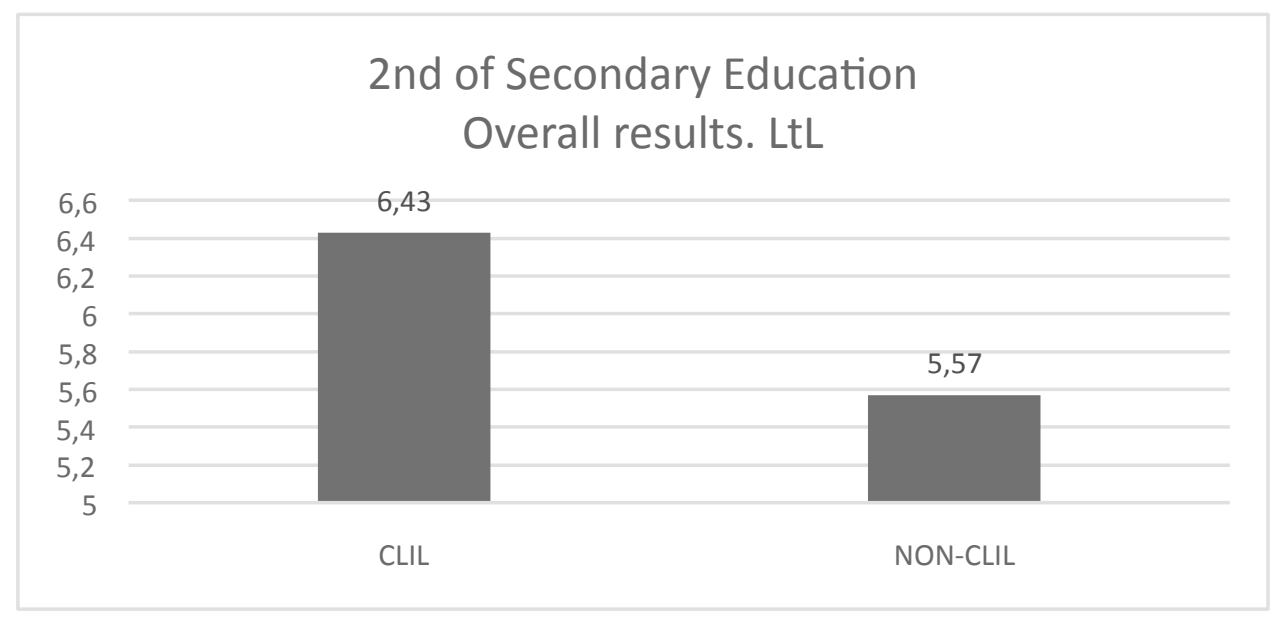

Figure 3. Learning to learn (LtL) in $2^{\text {nd }}$ year of Secondary Education. Overall results

These findings, which demonstrate the contribution CLIL has made to the significant development of cognitive and learning strategies, are in keeping with previous research in which it is stated that CLIL students use cognitive and metacognitive strategies more than their non-bilingual peers (Grisaleña et al., 2009) and that they successfully develop, according to the opinion of their teachers, lower and higher thinking strategies (Méndez, 2014).

Additionally, according to Reilly and Medrano (2009: 63), bilingual projects entail development of cognitive and social benefits which can be considered to be "by-products" of the CLIL methodology beyond its purely linguistic benefits. Following the authors, these "by-products" are not clearly observable until secondary school education, which is the context of our study. Among these "by-products", Reilly and Medrano (2009: 64) cite, development of "higher-order cognitive skills like questioning, summarising, predicting, hypothesising" and "independent learning and study skills". In the same vein, Marsh (2002: 201), labels the extra benefits inherent in this approach, as being the added value of CLIL, and particularly, "the enhanced development of learning strategies and skills, which are related to broader cognitive applications". These findings are in line with the results of this study which show that CLIL students displayed significant proficiency in the learning to learn skills and strategies when compared to their non-bilingual peers.

The double challenge of integrated content and foreign language learning makes it necessary for students to develop appropriate strategies "to make their learning more effective" (Halbach, 2009: 21) and therefore "development of CLIL methodologies have focused on cognition for some years" (Marsh, 2013: 74). The difficulty of assimilating new concepts and contents conveyed in a foreign language requires a methodology that enhances the construction of new learning and fosters learning to learn strategies. As Marsh (2013: 75) explains, bilingual education can be considered to be an opportunity to turn away from the banking concept of learning, based on depositing knowledge, in which students have to learn by heart without thinking critically, to a student-centred model, in which interaction 
and critical thinking are enhanced, and the cognitive processes and learning strategies of the students are developed.

On the other hand, the contribution CLIL methodology makes to the development of learning strategies and lower and higher order thinking skills (Coyle, Hood and Marsh, 2010) can explain the fact that bilingual students are more efficient learners (Jabrun, 1997), and display greater mastery in the key learning to learn competence, as shown in this paper.

However, we must be cautious about making generalizations based on the results of this study, since, despite the large number of participants, each context is different (Bonnet, 2012) and results derived from research conducted in different CLIL programmes might not be in keeping with the findings presented in this paper.

\section{Conclusion}

Secondary students in their $2^{\text {nd }}$ year (13-14 year-olds) enrolled in CLIL programmes in Castilla-La Mancha scored significantly higher than mainstream students when the key competence of learning to learn was assessed. CLIL students significantly outperformed their peers in both learning to learn dimensions, "meta-cognitive strategies" and "learning and self-regulation strategies". They also displayed significantly higher scores for all standards tested: "identification of own learning styles", "self-evaluation of results", "organization of information in conceptual maps", "integration of information in content sheets", "outlining the main ideas", "planning a written text" and "presenting clear and logically ordered texts."

The data analysed lead us to conclude that CLIL methodology has a positive effect on the development of learning to learn strategies. Moreover, benefits of CLIL, have been particularly detected in the dimension of learning and self-regulation strategies and in the development of higher order thinking skills. These outcomes seem to be the result of the CLIL methodology, which places more emphasis on the construction of learning than traditional approaches do, and provides students with learning strategies which may compensate for the difficulty of assimilating and processing new concepts by means of a foreign language.

\section{ACKNowledgements}

We would like to thank the Office of Evaluation of the Regional Ministry of Education of Castilla-la Mancha, which provided data for this study and especially its Director, Fernando Arreaza Beberide. We accept full responsibility for any errors made.

\section{REFERENCES}

Admiraal, W., G. Westhoff, \& de Bot, K. (2006). "Evaluation of Bilingual Secondary Education in the Netherlands: Students' Language Proficiency in English", in Educational Research and Evaluation, 12: 75-93.

Alonso, E., Grisaleña, J. \& Campo, A. (2008). "Plurilingual Education in Secondary Schools: Analysis of Results", in International CLIL Research Journal, 1, 1: 36-49. 
Anderson, L.W. \& Krathwohl, D.R. (eds.) (2001). A Taxonomy for Learning, Teaching, and Assessing: A Revision of Bloom's Taxonomy of Educational Objectives. New York: Longman.

Badertscher, H. \& Bieri, T. (2009). Wissenserwerb im content-and-language integrated learning. Bern-Stuttgart-Wien, Switzerland: Haupt.

Bergroth, M. (2006). "Immersion students in the matriculation examination three years after immersion”, in K. Björklund, M. Mård-Miettinen, M. Bergström \& M. Södergård (Eds.). Exploring Dual-Focussed Education. Integrating Language and Content for Individual and Societal Needs, available from http://www.uwasa.fi/materiaali/pdf/isbn_952-476-149-1.pdf, accessed 19 December, 2014.

Bialystok E., Craik F.I. \& Freedman, M. (2007). "Bilingualism as a protection against the onset of symptoms of dementia", in Neuropsychologia, 45, 2: 459-464.

Bonnet, A. (2012). "Towards an Evidence Base for CLIL. How to Integrate Qualitative and Quantitative as well as Process, Product and Participant Perspectives in CLIL Research", in International CLIL Research Journal, 1, 4: 66-78.

Butler, D. L. \& Winne, P. H. (1995). "Feedback and self-regulated learning: A theoretical synthesis". Review of Educational Research, 65: 245-281.

Cloud, N., Genesee, F. \& Hamayan, E. (2000). Dual language instruction: A Handbook for Enriched Education. Boston: Heinle \& Heinle.

Coyle, D. (2011). "Post-method pedagogies: using a second or other language as a learning tool in CLIL settings", in Y. Ruiz de Zarobe, J. Sierra \& F. Gallardo del Puerto (Eds.). Content and Foreign Language Integrated Learning. Berne: Peter Lang, 49-74.

Coyle, D. (1999). "Supporting students in content and language integrated contexts: planning for effective classrooms", in J. Masih. Learning through a foreign language - models, methods and outcomes. London: Centre for Information on Language Teaching and Research (CILT), 46-62.

Coyle, D., Hood, P. \& Marsh, D. (2010). CLIL: Content and Language Integrated Learning. Cambridge: CUP.

Cummis, J. \& Swain, M. (1986). Bilingualism in Education: Aspects of Theory, Research and Practice. New York: Longman.

Dalton-Puffer, C. (2008). "Outcomes and processes in Content and Language Integrated Learning (CLIL): current research from Europe", in W. Delanoy \& L. Volkmann (Eds.) Future Perspectives for English Language Teaching. Heidelberg: Carl Winter, 139-157.

Dalton-Puffer, C. (2011). "Content-and-Language Integrated Learning: From Practice to Principles?" Annual Review of Applied Linguistics, 31: 182-204.

Day, E. \& Shapson, S.M. (1996). Studies in Immersion Education. Ontario: Multilingual Matters.

De Jabrun, P. (1997). "Academic achievement in late partial immersion French", in Babel, 32, 2: $20-3$.

Fernández Cézar, R., Aguirre Pérez, C. \& Harris, C. (2009). "Implementation of CLIL in Castilla-La Mancha (Spain) and Teachers' Training”, in D. Marsh, P. Mehisto, D. Wolff, R. Aliaga, T. Asikainen, M.J. Frigols-Martin, S. Hughes, \& G. Langé (Eds.) CLIL Practice: Perspectives from the Field (pp. 21-27). University of Jyväskylä (Finland), available from http://www.icpj.eu/?id=3, accessed 19 December, 2014.

Fernández Cézar, R., Aguirre Pérez, C. \& Harris, C. (2013). "La formación de maestros en Aprendizaje Integrado de Contenidos en Lengua Extranjera (AICLE): un estudio en Castilla La Mancha", in Revista de Formación e Innovación Educativa Universitaria, 6, 1: 33-44, available from http://webs.uvigo.es/refiedu/Refiedu/Vol6 1/REFIEDU 6 1 3.pdf, accessed 19 December, 2014. 
Genesee, F. (1987). Learning through Two Languages: Studies of Immersion and Bilingual Education. Rowley, MA: Newbury House.

Genesee, F. (1991). "Second Language Learning in Schools Settings: Lessons from immersion", in A. Reynolds (ed.) Bilingualism, multiculturalism, and second language learning. Hillsdale, NJ: Lawrence Erlbaum, 183-201.

Genesee, F. (2008). Literacy outcomes in French Immersion. Monreal: Canadian Language and Literacy Research Network.

Grisaleña, J., Campo, A. \& Alonso, E. (2009). "Enseñanza plurilingüe en centros de educación secundaria: análisis de resultados", in Revista Iberoamericana de Educación, 49,1: 1-12.

Halbach, A. (2009). "The primary school teacher and the challenges of bilingual education", in E. Dafouz \& M.C. Guerrini (eds.), CLIL across educational levels. Madrid: Richmond Publishing, 19-26.

Housen, A. (2002). "Processes and outcomes in the European schools model of multilingual education", in Bilingual Research Journal, 26, 1: 45-64.

Jäppinen, A.K. (2005). "Thinking and Content Learning of Mathematics and Science as Cognitional Development in Content and Language Integrated Learning (CLIL): Teaching Through a Foreign Language in Finland", in Language \& Education, 19, 2: 148-169.

Jiménez Catalán, R.M. \& Ruiz de Zarobe, Y. (2009). "The Receptive Vocabulary of EFL Learners in Two Instructional Contexts: CLIL versus non-CLIL Instruction", in Y. Ruiz de Zarobe \& R.M. Jiménez Catalán, R.M. (eds.), Content and Language Integrated Learning. Evidence from Research in Europe. Bristol: Multilingual Matters, 81-92.

Kormi-Nouri, R., Shojaei, R.S., Moniri, S., Gholami, A.R., Moradi, A.R., Akbari Zardkhaneh, Saeed, C. \& Nilsson, L.G. (2008). "The effect of childhood bilingualism on episodic and semantic memory tasks", in Scandinavian Journal of Psychology, 49: 93-109.

Lamsfuß-Schenk, S. (2002). "Geschichte und Sprache - ist der bilinguale Geschichtsunterricht der Königsweg zum Geschichtsbewusstsein?”, in S. Breidbach, G. Bach \& D. Wolff (eds.), Bilingualer Sachfachunterricht: Didaktik, Lehrer-/ Lernerforschung und Bildungspolitik zwischen Theorie und Empirie. Peter Lang, 191-206.

Lapkin, S., Hart, D. \& Turnbull, M. (2003). “Grade 6 French Immersion Students' Performance on Large-Scale Reading, Writing, and Mathematics Tests: Building Explanations", in Alberta Journal of Education, 49: 6-23.

Lasagabaster, D. (2008). Foreign Language "Competence in Content and Language Integrated Learning", in Open Applied Linguistics Journal, 1: 31-42.

Lagasabaster, D. \& Ruiz de Zarobe, Y. (2010). CLIL in Spain: Implementation, results and teacher training. Newcastle upon Tyne: Cambridge Scholars Publishing.

Lagasabaster, D. \& López Belochi, R. (2015). "The Impact of Type of Approach (CLIL Versus EFL) and Methodology (Book-Based Versus Project Work) on Motivation", in Porta Linguarum, 23: 41-57.

Loranc-Paszylk, B. (2009). "Integrating Reading and Writing into the Context of CLIL Classroom: Some Practical Solutions", in International CLIL Research Journal, 1, 2: 46-53.

Lorenzo, F., Casal, S. \& Moore, P. (2009). "The Effects of Content and Language Integrated Learning in European Education: Key Findings from the Andalusian Bilingual Sections Evaluation Project", in Applied Linguistics, 31, 3: 418-442.

Lorenzo, F. (2010). "CLIL in Andalusia", in D. Lagasabaster \& Y. Ruiz de Zarobe (eds.), CLIL in Spain: Implementation, Results and Teacher Training. Newcastle upon Tyne: Cambridge Scholars Publishers, 2-11.

Madrid, D. (2011). "Monolingual and Bilingual Students' Competence in Social Studies", in D. Madrid and S. Hughes (eds.). Studies in Bilingual Education, Bern: Peter Lang, 195-222. 
Marsh, D. (2002). CLIL/EMILE - The European Dimension. Actions, Trends and Foresight Potential, Strasbourg, European Commission.

Marsh, D. (2013). The CLIL Trajectory: Educational Innovation for the $21^{\text {st }}$ Century iGeneration. Córdoba: Sevicio de Publicaciones de la Universidad de Córdoba.

Mehisto, P., Marsh, D. \& Frigols, M. J. (2008). Uncovering CLIL, Content and Language Integrated learning in Bilingual and Multilingual Education. Oxford: Macmillan.

Mehisto, P. \& Marsh, D. (2011). "Approaching the Economic, Cognitive and Health benefits of Bilingualism: Fuel for CLIL", in Y. Ruiz de Zarobe, J. Sierra \& F. Gallardo del Puerto (eds.). Content and Foreign Language Integrated Learning. Bern: Peter Lang, 21-48.

Méndez García, M.C. (2014). "A Case Study on Teachers' Insights into Their Students' Language and Cognition Development Through the Andalusian CLIL Programme", in Porta Linguarum, 22: 23-39.

Muñoz, C. (2002). "Relevance \& Potential of CLIL", in D. Marsh, CLIL/EMILE - The European Dimension. Actions, Trends and Foresight Potential, Strasbourg, European Commission, 33-36.

Naves, T. (2011). "How Promising Are the Results of Integrating Content and Language for EFL Writing and Overall EFL Proficiencyy?", in Y. Ruiz de Zarobe, J. Sierra \& F. Gallardo del Puerto (eds.), Content and Foreign Language Integrated Learning. Bern: Peter Lang, 103-128.

Navés, T. \& Victori, M. (2010). "CLIL in Catalonia: An Overview of Research Studies", in Y. Ruiz de Zarobe \& D. Lasagabaster (eds.), CLIL in Spain: Implementation, Results and Teacher Training. Newcastle upon Tyne, UK: Cambridge Scholars, 30-54.

Nieto Moreno de Diezmas, E. (2012). "CLIL and development of emotional competence", in Miscelanea. A Journal of English and American Studies, 45: 53-74.

Pérez Cañado, M. L. (2011). "The Effects of CLIL within the APPP: Lessons Learned and Ways Forward", in R. Crespo \& M. García de Sola (eds.). Studies in Honour of Ángeles Linde López. Granada: Universidad de Granada, 389-406.

Reilly, T. \& Medrano, P. (2009). "MEC/British council Bilingual project. Twelve years of bilingual education and a smooth transition into secondary", in E. Dafouz \& M.C. Guerrini (eds.), CLIL across educational levels. Richmond Publishing, 59-70.

Ruiz de Zarobe, Y. (2011). "Which Language competencies Benefit from CLIL? An Insignt into Applied Linguistic Research", in Y. Ruiz de Zarobe, J. Sierra \& Gallardo del Puerto, F. (eds.). Content and Foreign Language Integrated Learning. Berne: Peter Lang, 129-153.

San Isidro, X. (2009). "Galicia: Clil Success in a Bilingual Community", in D. Marsh, P. Mehisto, D. Wolff, R. Aliaga, T. Asikainen, M.J Frigols-Martin, S. Hughes \& G. Langé (eds.), CLIL Practice: Perspectives from the Field, (pp. 4-13). Jyväskylä: University of Jyväskylä, 4-13, Available from http://www.icpj.eu/?id=1, accessed 19 December, 2014.

San Isidro, X. (2010). "An Insight into Galician CLIL: Provision and Results", in D. Lasagabaster \& Y. Ruiz de Zarobe (eds.). CLIL in Spain: Implementation, results and teacher training. Newcastle upon Tyne, UK: Cambridge Scholars, 55-78.

Seikkula-Leino, J. (2007). "CLIL learning: Achievement levels and affective factors", in Language and Education, 21, 4: 328-341.

Smith, J \& Paterson, F. (1998). Positively Bilingual: Classroom Strategies to Promote the Achievement of Bilingual Learners. Nottingham; Nottingham Education Authority.

Stohler, U. (2006). "The acquisition of knowledge in bilingual learning: an empirical study on the role of language in content learning", in VIEWZ Vienna English Working Papers, 15, 3: $41-46$. 
Swain, M. \& Lapkin, S. (1982). Evaluating bilingual education: A Canadian case study. Clevedon, Eng.: Multilingual Matters.

Swain, M. \& Lapkin, S. (1986). "Immersion French at the Secondary Level: "The Goods" and "The Bads", in Contact, 5, 3: 2-9.

Turnbull, M., Lapkin, S. \& Hart, D. (2001). “Grade 3 Immersion Students' Performance in Literacy and Mathematics: Province-Wide Results from Ontario (1998-99)", in The Canadian Modern Language Review, 58: 9-26.

Van de Craen, P., Lochtman K., Ceuleers, E., Mondt, K. \& Allain, L. (2007). “An interdisciplinary approach to CLIL learning in primary schools in Brussels", in C. Dalton- Puffer, U. Smit (eds.). Empirical Perspectives on CLIL Classroom Discourse (pp. 253-274). Frankfurt am Main: Peter Lang, 253-274

Várkuti, A. (2010). "Linguistic Benefits of the CLIL Approach: Measuring Linguistic Competences", in International CLIL Research Journal, 1, 3: 67-79. 